\author{
Anna NIZIOL ${ }^{1}$ \\ Norbert ŻYCZYŃSKI ${ }^{2}$
}

\title{
AN INCREASE OF THE REGION'S COMPETITIVENESS THROUGH EFFECTIVE TOURIST PRODUCT MANAGEMENT: AN EXAMPLE USING THE THEMATIC TRAIL
}

\begin{abstract}
The present article explores the possibility of increasing the competitiveness of regions by creating interesting tourist products that are based on local resources. An example of such a regional tourist product is the thematic (or 'nature') trail. The issue of trail management is also discussed using an example of a cultural trail. This review article used verified data from publicly available existing sources, including specialist literature and the internet. In addition to publicly available data, we used a case study approach using examples of the Culinary Trail "Podkarpackie Flavours" and the "Wooden Architecture Trail" of the Małopolska Voivodship. We analyzed the case study to answer the following question: "Can a tourist product of a region used in a network structure (such as a thematic trail) affect the region's competitiveness?"
\end{abstract}

Keywords: region, competitiveness, management, tourist product, trail.

\section{REGIONAL COMPETITIVENESS}

The phenomenon of competition occurs in many areas of economic, social, artistic or sports life. Competitors compete with each other, striving to achieve similar or even the same goals at the same time. Often, competing means eliminating rivals and attracting their clients (Noga, 1993).

The effect of competition is competitiveness, which indicates the way in which companies compete in the market for customer demand.

An entity that is able to provide customers relevant goods and services at the right time and place, with good quality, meeting their expectations and needs, will be a more efficient, effective and therefore competitive (Kraszewska, Pujer, 2017).

Today, competitiveness means the ability of companies to be innovative, as well as flexibility in operation and the ability to adapt to the dynamics of market changes (Abbas,

\footnotetext{
${ }^{1}$ Anna Nizioł, PhD, Institute of Physical Education, Collegium of Medical Sciences, University of Rzeszów, Al. Rejtana 16 C, 35-959 Rzeszów, Poland; e-mail: aniziol@ur.edu.pl. ORCID: 0000-0002-9141-9135.

2 Norbert Życzyński, PhD, The Faculty of Management, Department of Management Systems and Logistics, Rzeszow University of Technology, ul. Akademicka 2, 35-084 Rzeszów, Poland; e-mail: n.zyczynski@prz.edu.pl. ORCID: 0000-0003-0681-3072 (corresponding author).
} 
2000). In order to gain a competitive advantage it is also important to manage knowledge resources (Hallin, Marnburg, 2008).

The competition and competitiveness can also be discussed in relation to spatial units. Regional competition may have a direct dimension, regarding competition for access to outside benefits, attracting investors, resulting in socio-economic development and raising the quality of life, as well as indirect - then local authorities act to improve the conditions of the regional environment for entrepreneurs (Nawrot, Zmyślony, 2009).

The intensive development of tourism in recent decades, manifested in an increase in the number of tourists, travel and generated income has caused that individual areas compete with each other. Cities and municipalities as well as regions undertake intensive efforts to attract tourists by creating attractive tourist products, promoting and distributing them so that a potential tourist chooses a given region as the destination.

In the light of the above arguments, competitive regions with a leading tourist function should be characterized by, among others (Szewczuk, Kogut-Jaworska, Zioło, 2011):

- an offer corresponding to the expectations of external investors,

- an ability to create friendly conditions for the functioning and development of entrepreneurship,

- an attractive tourist product based on own resources,

- efficient cooperation with the environment.

Nowadays, creating new, interesting tourist products of the region is fundamental to increasing the attractiveness of a given place, as well as, in the process of competition between tourist regions. According to Kruczek and Walas (Stasiak [red.] 2009), the tourist product of the region (also defined in literature as regional and territorial product, destination product) includes space availability, image, infrastructure, services and price. Therefore, it contains tangible and intangible elements, payable, partly payable and free of charge, offered, among others by tourist base managers (e.g. accommodation), self-government cultural institutions (e.g. museum), residents (e.g. hospitality) or the natural environment (e.g. landscape).

In order to program a new tourist product of the region and thus increase the competitiveness of a given area, it is necessary to ensure proper coordination of activities of various entities representing both the public and private sectors, often dispersed and focused on their own activities. The influence of a number of internal and external factors should also be taken into account. The first group includes factors closely related to the entity and its functioning on the market, and the second group includes the environment factors of the entity and factors directly affecting the created products, e.g. consumer needs and experience (Meyer, 2010).

The diversity of entities and interacting factors usually means a situation where there is a conflict of goals, interests and modes of action. There is a rivalry that negatively affects the functioning of the created product, and this leads to a disruption of its spatial structure, reduction of quality and reduction of tourists' interest in a given region. The solution in this case is coopetition, i.e. establishing partner relationships, cooperation within the framework of an integrated product, but also competing with each other for a tourist (Panasiuk, 2012). According to Panasiuk, an integrated tourist product should be identified with the offer of the area created jointly by tourist entrepreneurs, local government units and tourist organizations (Panasiuk, 2008). 


\section{THEMATIC TRAIL AS AN INTEGRATED TOURIST PRODUCT OF THE REGION}

The thematic trail is a special example of an integrated tourist product increasing the tourist attractiveness of the region, considered as an indicator of its tourist function. This type of trail consists of a series of "places" or "objects" associated with a certain thematic idea, connected to each other by a marked route (walking, water, car etc.) and a variety of tourist infrastructure located along the trail (Kaczmarek, Stasiak, Włodarczyk, 2010).

The trails are classified as complementary infrastructure, however, the higher their density, the more tourist traffic and the better developing tourist infrastructure can be counted on.

The thematic trail, as an integrated product, is also an example of an element of regular management of economic development in a given area. The trail allows you to concentrate tourist traffic on a large area by channeling it along selected routes, but also, on the other hand, limit excessive concentration of tourists in places threatened by their expansion by dispersing trail users over a larger space. It is worth mentioning that certain regions, so far not very popular among tourists, have been promoted in this way, and in some cases tourism has become the main factor for their development. Thematic trails, such as the Eagles' Nests Trail, Wooden Architecture Trail or Green Velo Bicycle Trail, mean that tourists, instead of going only to one of the most known places, visit several others. They do not have to look for other attractions, because traveling along the proposed route, they reach the surrounding monuments and places they have never heard of before. The combination of towns and monuments with the superior idea increases the attractiveness of each of the individual stops along the travelers' route.

The trail as a tourist product is characterized by complexity and multi-production. It consists of many individual goods and services that tourists use during their journey.

Kaczmarek and co-authors list six categories of tourist product that may be included in the route:

1. services - accommodation, catering, guide, tourist information,

2. things - guides, tourist maps, souvenirs, postcards, multimedia presentations,

3. objects - architectural monuments, technical monuments, museums, natural objects,

4. events - shows, presentations, cultural events, recreational events,

5. events (tourist packages) - city tours, trips in the area, stay offers,

6. area - city, commune, district, national park (Kaczmarek et al., 2010).

The relationships between individual components are multi-faceted and can be complicated by the fact that each of them has a different manufacturer. Creating one coherent product from many parts requires especially identifying the entity coordinating the activities of all producers of partial products. The role of administrator-coordinator may be performed by local government, regional and local tourist organizations, tourist associations (sometimes specially created for this purpose).

Kachniewska (2015) emphasizes that in creating a coherent network of cooperation within an area (spatial) product like a trail, legal and organizational separation of individual entities should be maintained. Proposes the use of repetition of certain actions aimed at increasing the quality and attractiveness of the offer under the model of creating a network tourist product. 


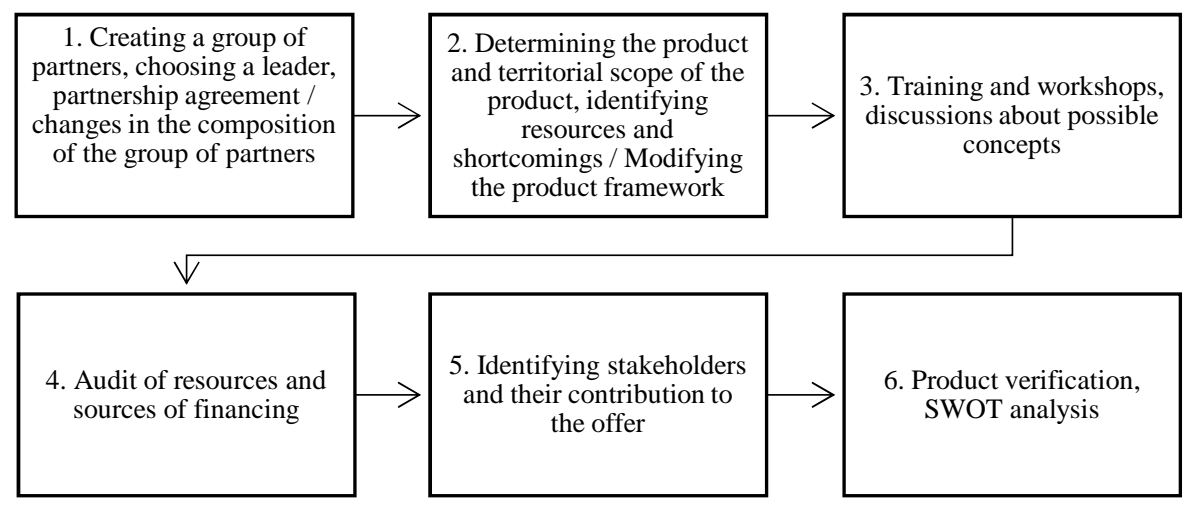

Fig. 1. Model of creating and improving a network tourist product

Source: (Kachniewska, 2015).

In practice, it is difficult to achieve equal involvement of all entities in trail management. It is worth specifying the requirements that the organizational structure of the thematic trail should meet. This will ensure not only its management in the operational phase (creation, organization) but also after its completion.

First of all, should be define a hierarchically ordered organizational structure. As already mentioned, local government units are often in such a structure. However, their competences in managing the thematic trail are not always fulfilled effectively.

Examples of tasks for individual self-governments in the field of thematic trail management, lists Gaweł (2011). He suggests that the provincial government, with the appropriate human resources, should enable route planning, trail marking, trail promotion as a brand (e.g. substantive supervision of promotional publications, organization of study tours), image creation, development of elements of visual identity, coordination of activities of other partners, support in obtaining external funds.

In turn, the county self-government would be responsible for creating tourist information points, distributing information materials about facilities in the county, coordinating the activities of municipalities, as well as cooperating with partners and stakeholders as part of developing the tourist services market on the trail.

The competences of municipalities may include taking care of the immediate surroundings of the trail, maintenance of information boards, ensuring constant time frame of accessibility to facilities, including trail proposals in the program of regional events, cooperation with municipal education institutions to develop educational programs for children and young people regarding the local cultural heritage, cultural identity etc., and cooperation with the owners of facilities to improve the quality of services (e.g. assistance in employing seasonal guides recruited from the local community).

If a given local government is not appointed as a leader in the network structure of a tourist product, it may be taken over, for example, by a non-governmental organization or a local tour operator.

Another solution is possible - a separate coordinator could be specifically appointed for this role, who would only organize the activity of the route in a different scope than it was at the stage of its creation. The tasks of this coordinator would relate to serving tourists and 
creating or mediating the development of specific offers, including the trail, its selected sections or individual facilities.

\section{THEMATIC TRAILS PROMOTING REGION}

A positive example of creating a regional product in the network formula is the Culinary Trail Podkarpackie Flavours. It has been operating for six years as the only active culinary trail in Podkarpackie Voivodship. It was created in 2013, originally associating 39 gastronomic facilities in a partnership. Currently, the trail has 48 places, including 42 restaurants, one vineyard, two confectioneries and three agritourism farms. It should be noted that this is one of the longest culinary routes in Poland, which distinguishes the Podkarpackie region on the map of the country.

From the beginning, the initiator, creator and coordinator of the trail was the Association for the Development and Promotion of Podkarpacie "Pro Carpathia". The proper management and harmonious cooperation between particular objects and the coordinator are worth emphasizing. The results of this cooperation are honors and awards gained by the trail. Among others, trail was the finalist of the contest for "The Best European Tourism Destinations EDEN - Tourism and local gastronomy" in 2015 (http:// gospodarkapodkarpacka.pl/news...), was awarded by the Polish Tourist Organization in the \#NaWsiNajlepiej contest in 2018, winning the second place in the category "Culinary routes offer in rural areas" (https://nawsinajlepiej.polska.travel/2018), as part of the National Geographic Plebiscite, in which Internet users chose "7 new wonders of Poland" - it was one of the candidates and took the seventh place in the vote, officially becoming one of the new wonders of Poland.

According to the representative of the trail coordinator, trips "with taste" distinguish Podkarpackie as a place where it is worth coming to eat tasty, interesting and in accordance with tradition. The trail contributes to exploring the entire region by seeking culinary experiences. On the trail you can try Lemko-Boyko, Pogórzańska, Lasowiacka and Old Polish cuisine, which was served in noble manors and magnate palaces. As Krzysztof Zieliński from the Pro Carpathia Association claims: "we transform the local tradition and delicacies of our cuisine into promotional success measured by the number of satisfied tourists" (https://nowiny24.pl/szlak-kulinarny-podkarpackie...).

The Culinary Trail Podkarpackie Flavours caused that regional dishes, drinks and specialties became the destination of many tourists to the Podkarpackie Voivodship. However, it is difficult to assess exactly how many tourists come to Podkarpackie because of the culinary route. The choice of tourist destination by tourist participants depends on so many factors that it is not easy to determine which ultimately affected arrival in a given region. According to information published by the Statistical Office in Rzeszów (https://rzeszow.stat.gov.pl/dla-mediow/informacje-prasowe...) on the total number of tourists choosing accommodation in Podkarpackie, it appears that in 2018 it was 37.4 thousand higher than in 2017. However, there were fewer foreign tourists (by 11.7 thousand people). In 2018, all tourists were provided with accommodation by 155.4 thous. more than a year ago. It is not excluded that such a result was noted, among others, thanks to the offer of The Culinary Trail Podkarpackie Flavours.

In turn, according to research conducted in 2018 by Exacto LLC, commissioned by the Podkarpacka Regional Tourist Organization, Podkarpackie Voivodship turned out to be one of the most often visited region by domestic tourists, giving way to the Pomorskie and 
Małopolskie provinces. Respondents (1,500 inhabitants of Kraków, Warszawa and Wrocław) indicated that one of the significant assets of the studied region that would make them come to this part of Poland are traditional dishes (29.4\%) and interesting themed trails (26.4\%) (https://podkarpackie.travel/assets/media...).

It is important that the tourist offer is varied and the promotional message is consistent and builds a strong image of the place. The culinary trail as a product of the region guarantees a variety of offers for tourists, however, entrepreneurs alone without the support of entities responsible for tourism at various levels are not able to provide large-scale promotion.

Another example of the trail numerously visited by tourists, not only from Poland but also from abroad, is the Wooden Architecture Trail (WAT). It is a tourist trail created in cooperation with four provinces: Świętokrzyskie, Śląskie, Małopolskie and Podkarpackie. WAT was created in the years 2001-2003. A few years later, in 2008-2009, the Wooden Architecture Trail in the Świętokrzyskie Province was also marked (https://pl. wikipedia.org/wiki/Szlak_Architektury_Drewnianej). This trail is the oldest cultural trail marked out in Poland and includes, among others small-town and health resort complexes, open-air museums, palaces, churches and orthodox churches, some of which have been inscribed on the UNESCO World Cultural and Natural Heritage List.

Despite the fact that this trail was marked out in four voivodships, it can only be stated on the example of the WAT of the Małopolska Voivodship that the trail is "lively", active and open to tourists. It is also the richest in terms of cultural resources (nearly 250 objects connected by a route with a length of $1500 \mathrm{~km}$ ) (Gawel, 2011) part of the trail and most visited by tourists (about 1 million per year) (Bogacz-Wojtanowska, Gaweł, Góral, 2016). The activity of the Małopolska WAT is the result of cooperation between the Marshal's Office of the Małopolska Voivodship and the Małopolska Tourist Organization (MOT), which was initiated in 2008 in the implementation of the Open Wooden Architecture Trail project. Since then, the thematic offer of the trail as a product has been increased, various events on the trail have been organized (including the Enchanted Music in Wood Festival, Christmas carol concert Małopolska Cultural Heritage Days, WAT Open Days). In addition, the condition of the trail marking and boards is constantly monitored.

In key places, i.e. most visited by tourists, there are collective tables with the entire course of the trail in several language versions. It was ensured that the facilities on the trail (not directly supervised by another institution) in the summer season, i.e. from May 1 to September 30, were open to visitors, photo and film competitions are organized, study visits take place, promotional publications are issued, and television programs are implemented, educational workshops.

Despite many successful implementations with the use of the Małopolska WAT facilities, there is a need to improve the trail management process, conduct continuous research on recipients along the trail (e.g. modeled on studies in open WAT facilities from 2008, the results of which showed the great popularity of the tourist product) (Gawel, 2011) and contact with stakeholders of this tourist product. However, according to Gawel, "SAD management cannot be reduced solely to care for individual monuments and promotional activities aimed at increasing the number of visitors. It is necessary to pursue a sustainable development policy" (Bogacz-Wojtanowska et al., 2016). The richness of culture will ultimately determine the attractiveness of the trail, "we can tempt - with a string of wooden architecture beads. The French, Germans and Austrians envy us the last relics of wooden construction" (Zieja, 1999). 


\section{CONCLUSION}

Over the past decades, tourism has become an important factor for many regions in developing and competing for tourist demand. In search of sources of competitiveness, new tourist products of the region have been programmed. Numerous thematic routes have arisen in many regions and encourage to explore the richness of cultural, natural or industrial heritage. Such ideas resulted in the distinction on the map of tourist destinations that offer interesting, original and unique tourist products on a national and sometimes European and world scale. Trails are usually network products that stimulate social, economic or cultural changes in regions. Competing by creating tourist products of the region has contributed to the benefits of developing local enterprises, activating society and attracting investment. In this context, skillful route management plays an important role, which should take into account the goal of sustainable development.

\section{REFERENCES}

Abbas, A.J. (2000). Rethinking competitiveness, „Advances in Competitiveness Research” No. 8.

Bogacz-Wojtanowska, E., Gaweł, Ł., Góral, A. (2016). Szlaki kulturowe jako medium zmian w kulturze. Kraków: Stowarzyszenie Gmin i Powiatów Małopolski.

Gaweł, Ł. (2011). Zarzadzanie Szlakiem Architektury Drewnianej w kontekście procesu profesjonalizacji szlaków kulturowych. „Turystyka Kulturowa”, www.turystykakulturowa.org, No. 1.

Hallin, C.A., Marnburg, E. (2008). Knowledge management in the hospitality industry: A review of empirical research. „Tourism Management” Vol. 29, No. 2.

http://gospodarkapodkarpacka.pl/news/view/11309/podkarpackie-smaki-wsrod-najlepszycheuropejskich-destynacji-turystycznych

https://nawsinajlepiej.polska.travel/2018.html

https://nowiny24.pl/szlak-kulinarny-podkarpackie-smaki-na-liscie-7-nowych-cudow-polski/ar/ 12459360

https://pl.wikipedia.org/wiki/Szlak_Architektury_Drewnianej

https://rzeszow.stat.gov.pl/dla-mediow/informacje-prasowe/turysci-na-podkarpaciu-w-2018roku, 172,1.html

Kachniewska, M. (2015). Model tworzenia sieciowego produktu turystycznego. Warszawa: MROT.

Kaczmarek, J., Stasiak, A., Włodarczyk, B. (2010). Produkt turystyczny. Pomyst, organizacja, zarządzanie. Warszawa: PWE.

Kraszewska, M., Pujer, K. (2017). Konkurencyjność przedsiębiorstw. Sposoby budowania przewagi konkurencyjnej. Wrocław: Exante.

Kruczek, Z., Walas, B. (2009). Nowoczesne postrzeganie promocji kulturowych produktów turystycznych [w:] Stasiak, A., red., Kultura i turystyka - wspólnie zyskać. Łódź: Wydawnictwo WSTiH.

Meyer, B. (2010), Nowe trendy w kształtowaniu produktów turystycznych. „Acta Oeconomica” 9(4).

Nawrot, Ł., Zmyślony, P. (2009). Międzynarodowa konkurencyjność regionu turystycznego. Kraków: Proksenia.

Noga, A. (1993), Dominacja a efektywna konkurencja, Warszawa: SGH. 
Panasiuk, A. (2008). Gospodarka turystyczna. Warszawa: Wydawnictwo Naukowe PWN.

- red. (2013). Marketing w turystyce i rekreacji. Warszawa: Wydawnictwo Naukowe PWN Research on the tourist potential of the region and preferences of the target group for the purposes of creating new cross-border products in the Podkarpackie Voivodship, Summary of the Quantitative Research Report developed as part of microproject No. INT /EK/PO/1/ II/B/0157 entitled: "Carpathian Adventure - new cross-border travel products", Rzeszów 2018. Access on the internet: https://podkarpackie.travel/assets/media/prot-streszczenie-pl.pdf Szewczuk, A., Kogut-Jaworska, M., Zioło, M. (2011). Rozwój lokalny i regionalny. Teoria i praktyka. Warszawa: C.H. Beck.

Zieja, T. (1999). Szlakiem architektury drewnianej. „Przekrój” No. 18/2810.

DOI: $10.7862 /$ rz.2020.hss.4

The text was submitted to the editorial office: November 2019.

The text was accepted for publication: March 2020. 